\title{
Edyth von Haynau, Edyth Arnaldi and Rosa Rosà: One Woman, Many Souls
}

\section{Lisa Hanstein}

Kunsthistorisches Institut in Florenz

\begin{abstract}
In an atmosphere marked by the rise of feminism, the search for a renewal in art, and a strong fascination for paranormal phenomena, Edyth von Haynau created works of art including drawings, paintings and ceramics. She also wrote various articles in which she analyzed the positive change in the role of women.

The project focuses on how von Haynau used literary and artistic strategies to take up highly topical issues of her time and to reflect these scientific, technological and spiritist discoveries in a new female ideal. It aims to completely document and reconstruct her works beyond her Futurist phase in order to recontextualize von Haynau's impact on the renewal of the image of women and on the artistic trends of her time.
\end{abstract}

Studying a woman who was successfully practicing art in Italian Futurism (1909-1944), ${ }^{1}$ inevitably leads to gender-related questions since this avantgarde movement had long been considered misogynous. It was not until the 1980s that an increasing number of studies on female Futurist artists could revise this image by revealing the surprisingly high level of participation of women from many different nationalities in the movement. ${ }^{2}$

1 As this is a description of an ongoing project, the content will overlap with: Hanstein, "Edyth von Haynau"; Hanstein, Der Geist der Moderne; and Hanstein, "Durch Rosas Brille". I would like to thank the grandchildren of the artist, Cristina, Luca and Ranieri Fornari, for their kind permission to publish the works of Edyth von Haynau.

2 See Berghaus, 2015, pp. XI-XXII. An extensive review of the literature on female Futurist artists can be found in the same volume by Meazzi, 2019, pp. 450-464. The current state of research on female Futurists in Italy and Russia as well as publications on this topic are documented by Re/Douglas, 2019, pp. 47-66. 
Filippo Tommaso Marinetti (1876-1944) hoped that the provocative ideas and the aggressive tone of the Founding Manifesto proclaiming Futurism on 20 February, 1909, would be a wake-up call for Italy's youth. He was partly successful; his glorification of the "disdain for women" caused particular outrage and was discussed in many respects. ${ }^{3}$ Marinetti's "negative attitude towards women" was reflected by his contemporaries as well as by scholars and could eventually be put into perspective as it addressed an outdated, firmly established perception of femininity. ${ }^{4}$

While some female artists felt disgusted by the harsh ideas expressed in the manifesto, others saw its radical nature as an opportunity to distance themselves from the predominant female ideals in Italy at the time and they supported the departure from traditional values and clichés. ${ }^{5}$ Later on, Marinetti himself was to recognize and support these women as "potential allies in the explosion and destruction of the bourgeois family and the entire existing order." 6 Curiously, many of the women who were interested in Futurism for its anti-bourgeois sentiments were not Italian. ${ }^{7}$

One of these artists was Edyth von Haynau (1884-1978). ${ }^{8}$ She experimented with Parole in libertà (Words in Freedom)-a Futurist innovation which increasingly focused on the visual aspect of writing and which

3 "Noi vogliamo glorificare la guerra - sola igiene del mondo - il militarismo, il patriottismo, il gesto distruttore dei liberatori, le belle idee per cui si muore e il disprezzo della donna", Filippo Tommaso Marinetti, Manifesto del futurismo (Le Figaro, February 20, 1909). Point 9 was one of the most famous proclamations of the founding manifesto. In the following point, Marinetti explicitly opposed feminism.

4 For further reading, refer to Lucia Re who was among the first to investigate the complex relations of "Marinetti's paradoxical support for the suffragist movement. "See $R e, 1989$, p. 258. An overview on the state of research on this topic is provided by Berghaus, 2015, pp. XIV-XX, and Re/Douglas, 2019, pp. 49-51.

5 On the cultural, political, and social situation of the early $19^{\text {th }}$ century and the hesitant evolution of feminism in Italy as well as on the developments in Russia, see also: Re/Douglas, 2019, pp. 47-66.

6 See Re/Douglas, 2019, p. 51.

7 Also argued by $R e, 2011$, p. 2.

8 Her Futurist pseudonym Rosa Rosà was most likely based on the name of the small town Rosà (Veneto) which she duplicated. On Edyth's biography and this interpretation of her artist's name, see Salaris, 1981, pp. 27-28. This information cannot be confirmed by any sources and comes from interviews with the artist's descendants. At this point, I would like to thank Claudia Salaris for providing me with this piece of information. After her Futurist experience, Edyth signed her works mostly with "Edyth Arnaldi". Dr. Simonetta Proietti was the first scholar to provide an official document with the artist's death certificate; however, this contained an Italian variant of the name (Edith de Haynau). Her husband's death cer- 
blurred the lines between literature and the visual arts. She also wrote several short stories and a novel, was active as a painter, illustrator, ceramist and photographer. It would appear that she was also actively involved in the art of sculpture, which, unlike the applied arts, was still considered a male domain in 1939. ${ }^{9}$ Unfortunately, the whereabouts of any of her surviving sculptures and ceramics is unknown. Two of the artist's letters to Emilio Settimelli (1891-1954) confirm that ceramics was an important art form for Edyth. ${ }^{10}$ In Futurist art houses, such as Fortunato Depero's Casa del Mago in Roverto and the Casa Balla in Rome, many women were significant contributors to the applied arts. Apart from Benedetta (Cappa Marinetti 1897-1977), who became a famous Futurist painter, and the female artists associated with the periodical L'Italia Futurista, women were mostly overshadowed by their male colleagues or relatives and not appreciated by academia until later. ${ }^{11}$ For some female Futurist artists, their interest in designing Futurist fans, carpets and clothes posed a dilemma as they felt obliged to deliberately distance themselves from these areas in order to not propagate stereotypes and clichés. ${ }^{12}$ Edyth, however, lived out her artistic creativity in many areas, reflecting the spirit of Futurism. She also took a feminist stance in both her creative and critical writings, as emphasized by Lucia Re. ${ }^{13}$ Her talent was appreciated by her colleagues and the founding father of Futurism even called the Viennese artist a brilliant genius. ${ }^{14}$ Nevertheless, for a long period of time, Edyth almost fell into obscurity. This was due in part to the focus on the artistic work of her male colleagues by scholars of Futurism. According to Berghaus, male critics of art and literature were not interested in most of the female Futurists. Women were neither mentioned in the general literature on twentieth century art nor in studies focusing on Futurism. ${ }^{15}$ Another reason for her

tificate, though, gives another version of the name: Editha De Haynau. I would like to thank Dr. Proietti for forwarding these documents.

9 On women and sculpture see Grasso, 2001, p. 137.

10 The letters are stored in the archive of the Fondazione Conti in Fiesole (FC/ES.C 143-145 CAM A).

11 See Ruta, 2019, p. 186-187.

12 Among others, Zoccoli, 2019, p. 148 points at this problem.

13 Lucia Re argues this and calls Edyth the only female Futurist author who decisively opposed Marinetti's misogynist attitudes, see $R e, 1989$, p. 263.

14 In a conversation with Maria Ginanni, Marinetti called Edyth "la geniale Viennese" ("the brilliant Viennese lady"), documented by Marinetti, 1992, p. 130.

15 Furthermore, later Feminist studies sought distance because of Marinetti's "misogynist" rhetoric and his proximity to Fascism. See Berghaus, 2015, p. X. 
obscurity is the loss of the majority of Edyth's art works, as well as the fragmentary pieces of information on her life. ${ }^{16}$

Nevertheless, the artist's early years are relatively well-documented. Due to her "typically female" interest in drawing and music, she met the ideal of a young Austrian woman at the turn of the century. ${ }^{17}$ Edyth was part of the Viennese aristocracy and was educated at home. ${ }^{18}$ At the age of 13 , she witnessed the formation of the Vienna Secession which rebelled against the established concept of art. In order to be able to pursue her artistic education, Edyth, against her parents' wishes, attended the "Kunstschule für Frauen und Mädchen" (Academy of Arts for Women and Girls) in Vienna. ${ }^{19}$ It was not until 1920 that female students were admitted into the Academy of Fine Arts Vienna. ${ }^{20}$ In order to counteract the discrimination against female artists, women took action by founding the "Verein der Schriftstellerinnen und Künstlerinnen in Wien" (Association of Female Authors and Artists in Vienna) in 1885, which still exists today. ${ }^{21}$

Thus, Edyth grew up in an environment marked by revolutionary changes, the rise of feminism and the quest for a renewal of art. In addition, a strong interest in paranormal phenomena was characteristic for the Viennese society of the early twentieth century. Spiritism was particularly popular among scientists, artists and members of the Vienna upper class

16 As reported by Salaris, Edyth's immediate family criticized her association with Futurism and thus, most of her works were lost after her death, as quoted in Salaris, 2001, p. 53.

17 The image of the "Angel in the House" was, in addition to the image of "femme fatale" and the "femme fragile", the dominating stereotype, see $R e, 2001$, p. 2. On women's roles as artists in Vienna see also Plakolm-Forsthuber, 1994.

18 Such biographical information can be found in Salaris, 1981, p. 27.

19 The "Wiener Frauen Akademie" ("Women's Academy of Vienna"), as it was latter called, was founded by the painter Prof. A. F. Seligmann on December 1, 1897, who was the only teacher. http://www.onb.ac.at/ariadne/vfb/ms_kfmw.htmMore information on the history of women studying at the Academy of Fine Arts Vienna can be found on the Website of the Academy http://www.akbild.ac.at/Portal/a kademie/uber-uns/Organisation/arbeitskreis-furgleichbehandlungsfragen/geschich te. Investigation into the archives has revealed that Edyth enrolled neither at the University of Music and Performing Arts Vienna nor at the University of Applied Arts Vienna (formerly Vienna School of Arts and Crafts).

20 It was at a relatively late point in history that the Ministry of the Interior and Education officially allowed women to study at the Academy of Fine Arts Vienna, c.f. http://www.akbild.ac.at/Portal/akademie/uber-uns/Organisation/arbeitskreis-fur-g leichbehandlungsfragen/geschichte. For a historical overview of the development of women studying at the University of Vienna, refer to Heindl/Tichy, 1990.

21 On the tasks and goals of the society see Harriman, 1989, p. 27, as well as the information provided on: http://www.onb.ac.at/ariadne/vfb/fv_vsk.htm. 
around $1900 .{ }^{22}$ Due to Edyth's aristocratic background, it is likely that she witnessed discussions on this highly topical theme. Spiritism was not only relevant for modern $\operatorname{art}^{23}$ but also concerned with social issues. According to Astrid Kury, spiritism was also crucial for the increasing emancipation of women, as their role had already been reconceptualized in spiritist circles of the late $19^{\text {th }}$ century. ${ }^{24}$ I believe that young female artists who were open to this trend found it easier to join Futurist circles.

In Italy, spiritist tendencies also had an effect on modern art and, surprisingly, many female Futurists showed an interest in occultism. Silvia Contarini assumes that Marinetti and Valentine de Saint-Point (18751953) - who wrote the Manifesto of the Futurist Woman in 1912 and thus formulated a new female ideal—met in Paris at different spiritist séances. ${ }^{25}$ Benedetta, a student of the Futurist artist Giacomo Balla (1871-1958) and wife of Marinetti, was also attracted by occultism, which is particularly evident in her abstract novel Le forze umane (The Human Forces, 1924). ${ }^{26}$ She, in turn, was close friends with the Czech artist Růžena Zátková (18851923) who was to approach Futurism in Rome after 1914. Detailed entries in Rủžena's diary document her interest in paranormal phenomena, Rudolf Steiner's Anthroposophy, theosophic teachings and in the spiritist activities of the communities she frequented. ${ }^{27}$ She also organized séances in her home, and among the guests was also Balla, who lived in Rome. ${ }^{28}$ Balla's spiritist background, his contact with General Ballatore and the impact of these interests on his paintings and sculptures have been convincingly demonstrated in several studies. ${ }^{29}$ Balla's house, in turn, was a meeting point for Futurists. For example, the brothers Ginna (Arnaldo Ginanni

22 Explained in-depth by Kury, 1998, p. 390.

23 The role of spiritism in modern art is impressively analyzed in another study by Kury, 2000. The influence of occultism on modern literature was convincingly described by Pytlik, 2005.

24 This was also due to the implementation of Charles Fourier's Socialism, see Kury, 1998 , p. 396.

25 See Contarini, 2015, p. 94.

26 Marinetti Cappa, 1924.

27 Documented by Giorgini, 2012, p. 113.

28 On Růžena's relationship to Futurism and her sojourn in Rome, refer to Pomajzlová, 2011, in particular p. 287. Balla's presence at a séance taking place in Růžena's house is also documented by Giorgini, 2012, p. 115.

29 Carlo Ballatore (1839-1920) was president of the Theosophic Group in Rome which was founded in 1897 and which became part of the Theosophical Society in 1907, see Benzi, 2007, p. 121. As early as 1967, Calvesi pointed to the theosophical background of some of Balla's works, see Calvesi, 1967. Later studies confirmed his approach. 
Corradini, 1890-1982) and Corra (Bruno Ginanni Corradini, 1892-1976), members of the group associated with the Florentine periodical L'Italia futurista (1916-1918), which was to become very important for Edyth, discussed occult phenomena at this location. ${ }^{30}$

In 1908, Edyth married the Italian author Ulrico Arnaldi (1878-1956) and moved to Rome with him. There, she most likely encountered an atmosphere similar to Vienna in which paranormal phenomena were discussed. It seems likely that Edyth moved in similar circles to Rưžena and Balla, and attended events of the Associazione Artistica Internazionale in the famous Via Margutta where she kept a studio like so many other foreign artists. ${ }^{31}$ However, a direct connection has not been confirmed so far. ${ }^{32}$ Furthermore, there is no evidence of her first contact with the Futurist circle in Florence. Yet, it was mainly throughout her Futurist period as Rosa Rosà and her contributions to the periodical L'Italia futurista that she became famous.

The women involved with L'Italia futurista were united by a Feminist agenda as well as by their interest in the paranormal. ${ }^{33}$ Men of the main group associated with the periodical also shared this interest since a need for renewal could clearly be felt in Florence, which was derided by Futurists as just another "passatist" 34 city of museums. Investigating unknown

30 Poggianella, 1995, p. 461. The periodical L'Italia futurista is part of the project Pro Firenze Futurista - Digital archive on Futurism in Florence of the Kunsthistorisches Institut in Florenz - Max-Planck-Institut and can be consulted online: http://futur ismus.khi.fi.it/.

31 Between 1909 and 1915, Edyth and Ulrico had four children, see Salaris, 1981, p. 27. She was most likely introduced into Roman society during this period. Balla and Boccioni are listed as members and visitors of the Associazione Artistica Internazionale, see Moncada di Paternò/Salmeri, 2012, p. 314. The information on Edyth's studio in the Via Margutta is also confirmed by Verdone, 1971, p. 56. This reference can possibly be traced to the artist herself. But her name is not mentioned in an extensive study on artists in the studios in Via Margutta, see Moncada di Paternò/Salmeri, 2012.

32 So far, there is no evidence for connections with Růžena Zátková. I am grateful to Marina Giorgini for this important piece of information.

33 Of interest is Chapter 3 "Le veggenti del Futurismo: Le donne de "L'Italia futurista” tra esoterismo e diritti femminili”, in Mosco, 2009, pp. 87-133.

34 Condemning everything not modern to be old and unnecessary, the Futurists labeled several things "passatist" (from "passato" = "past") to contrast with the name of their own movement. 
phenomena was a means of achieving this. ${ }^{35}$ In the early twentieth century, it was commonly believed that space was permeated by invisible natural forces. The discoveries of hitherto unknown radiation, energies and magnetic waves highlighted the obvious limitations of human perception. Scientific discoveries and occult phenomena were often connected, as they could now be "proven" by science. Thanks to new technological means, perception exceeded the capabilities of the naked eye. Exactly the same was supposed to be achieved by the refined eye of the sensitized artist who visualized the invisible through art. ${ }^{36}$ This phenomenon pervades Edyth's otherwise very disparate works that were created between 1917 and 1918, and mainly published by L'Italia futurista or others in its circle. She evokes, for example, the vision of a modern city in which "the almost visible rays, the emanations of the brains, the awareness of virtues, the bright passions hover in the air." 37 Edyth's words describe the energies that are not visible to the naked eye, which had been discovered by the sciences and enthusiastically adopted by the parasciences. The title of Edyth's novella Romanticismo sonnambulo (Somnambulistic Romanticism, 1917), by contrast, confirms her interest in the phenomenon of sleepwalking. ${ }^{38}$ In addition, there are parallels to the practice of automatic writing and the theosophical principle of reincarnation with gender changes. ${ }^{39}$

In the Parole in libertà titled Ricevimento-thé-signore-nessun uomo ${ }^{40}$ (Reception-Tea-Ladies-No Men, 1917, Fig. 1) the artist's interest in invisible forces again becomes evident. The plate can be interpreted as a simplified floor plan of a salon. At its center, a small table with sandwiches and drinks is indicated by a circle. Asterisks, triangles and squares mark three discussion groups that are arranged around this circle and scraps of conversation radiate from them as wavy lines. The general mood between the

35 Simona Cigliana illustrates the general atmosphere in Florence as well as the special role of Futurists around the periodical L'Italia futurista, see Cigliana, 2002, pp. 47-66 and pp. 269-296. On the influence of the esoteric and occult on the contents of L'Italia futurista see also Notte, 2002, pp. 414-416. Besides the subscribers of the manifesto La scienza futurista (The Futurist Science), female artists such as Maria Ginanni and Irma Valeria shared their interest in the unknown, invisible and occult. The spiritist trend was rejected, though, by Magamal, 1917, p. 3.

36 See Dalrymple Henderson, 1995, pp. 13-31. Asendorf, 1989, also shows that the fascination for occult forces was not limited to Futurism. On the realization in Futurist art see also Hanstein, 2015.

37 See Rosà, L'Italia futurista 2(9), 1917, p. 3.

38 The text was also published in L'Italia futurista, 2(17), 1917, p. 3.

39 See Notte, 2002, p. 414.

40 Depicted in L'Italia futurista 2(35), 1917, p. 3. 
ladies in the room-marked by malicious gossip — is visualized in the main themes mentioned and by three flowing currents (Fluidi) that move between the groups: "Impertinenza" (impertinence), "Fluidi ostili" (hostile vibrations) and "Noia sbadiglie represse" (suppressed bored yawns). An "ugly family picture" (brutto quadro di famiglia) completes the scene. The author's location is indicated in the lower corner on the left as being in front of the door. The arrow as well as the phrase "mi pare che ne ho abbastanza" (I think I've had enough) show that she intends to leave the scene. Thus, the atmosphere in the room and Edyth's state of mind, her aversion towards the tea receptions typical of her social class and time, are clearly depicted. As the work's title accentuates, traditionally only women participated in such events. The social setting shown by Edyth's Parole in libertà was traditionally the domain of women and therefore contrasts strikingly with the setting of experimental séances, which were also organized in the salons of the high society, but which were mainly attended by men.

Edyth's novel Una donna con tre anime (A Woman with Three Souls, 1918), an early example of Feminist science fiction, ${ }^{41}$ also takes up topics such as esotericism, mediumism and telepathy. ${ }^{42}$ The author's critical attitude towards the bourgeois society and the traditional role of women emerges again ${ }^{43}$ as she describes the successive transformation of a housewife into three radically new models of femininity triggered by the touch of "spores from the future." 44 Capturing multiple personalities was also a popular issue in contemporary literature resulting in descriptions of fluent transitions of the self. ${ }^{45}$ A particularly vivid example is Luigi Pirnadello's novel Uno, nessuno, centomila (One, None, One Hundred Thousand, 1926) - parts of which had been previously published with Edyth's drawing Danzatrice (Female Dancer, Fig. 2)—so she must have been familiar with

41 See entry on Science Fiction by Pizzo/Somigli, 2006, pp. 1717-1718.

42 Bello Minciacchi, 2007, p. 162.

43 The novel connects Futurist principles with a fantastical quest for gender identity and occult topics. See Salaris, 1981, pp. 12-14. Additional information in Sica, 2004. The English edition of the novel by Lucia Re und Dominic Siracusa sparked new interest and international popularization, see Rosà, 2011, also available online: http://www.escholarship.org/uc/item/7k625747.

44 See Rosà, 1981. Salaris already grounded the number of different souls on Rosà's interest in occult sciences and the teachings of Rudolf Steiner. The theosopher had suggested a tripartition of the elements which constituted the human being (physical body, astral body, etheric body), see Salaris, 1981, p. 13.

45 On the representation of this topic in literature, see Asendorf, 1989, p. 78. 
it. ${ }^{46}$ Engaging with polypsychism was naturally interesting from a psychological point of view. The spiritists, however, were to delve deeply into the possibility of duplicating the body and the soul and Futurist artists later on reflected on this phenomenon in their works. ${ }^{47}$ Edyth not only took up this notion in Una donna con tre anime, but also in her illustrations for Bruno Corra's novel Sam Dunn è morto (Sam Dunn is Dead, 1917) ${ }^{48}$ which visualize invisible natural forces, vibrations and various states of mind. In her drawings for Mario Carli's volume Notti filtrate (Filtered Nights, 1918), she successfully captures the atmosphere of the juxtaposed poems way beyond the written word. ${ }^{49}$ What is also special about these illustrations, according to Zoccoli, is that they "anticipated the automatic writing of Surrealism" as the artist's hand traces "the flow of sensations surfacing from her inner depths" like a seismograph. ${ }^{50}$ The homogenous composition of text and image in pure shades of blue intensifies the somnambulistic impression suggested. Furthermore, this could be a reference to Edyth's and Mario Carli's unusually strong abilities of perception: infrared-photographs show that human perception is limited with regards to the color scale-an insight which was to change the world view of that time and which was to find its way into the works of some Futurists. ${ }^{51} \mathrm{~A}$ preliminary drawing, possibly by Edyth (Fig. 3), for the fifth image in the book

46 Pirandello had started working on this novel as early as 1909. The final version, however, was not published until 1926. Accompanied by Edyth's drawing it was published in Anton Giulio Bragaglia's magazine Cronache d'attualità. Arte, scienza, letteratura, teatro, mode, sport, mondanità, Rome, May 1921, Ser. 3, 5, p. 4.

47 On the possibility of the multiplied human and the externalization of the will, see also Marinetti, 1983, p. $256 \mathrm{ff}$. In occultism, the idea of an ethereal doppelganger is connected with the concept of multidimensionality. The Futurist Luigi Russolo, for example, reflected on this in his 1938 book Al di là della materia (Beyond Matter) and in some of his paintings. See Russolo, 1938.

48 Corra, 1917. For a detailed analysis of the drawings, refer to Hanstein, 2015 and Hanstein, 2019.

49 Carli, 1917.

50 See Zoccoli, 2019, p. 381.

51 This can be compared with the recently discovered ability to see laser light which lies beyond the visible spectrum and was therefore considered to be invisible to the human eye. On this see Palczewska et. al., 2014. According to Boccioni, blue and purple shades were to represent a purely spiritual perception of the modern world as an expression of a deeper understanding of reality. See Schiaffini, 2002, p. 82. Boccioni partly applies Hugo Magnus's theory in order to express the movement of the future, see Meighan, 1998, pp. 212-213. On the development of the perception of color, see Magnus, 1877; as well as the contribution by Schöntag, 2005, in particular pp. 297-300. 
Notti filtrate (no title, Fig. 4) might refer to the previous use of colors which was abandoned in favor of the more innovative version in blue. ${ }^{52}$

Edyth, however, not only worked as an artist. In her articles published in L'Italia futurista, she analyzed the positively changing role of women resulting from the absence of men who had been sent to the front..$^{53}$ In addition to its fascination for occult sciences, the group around L'Italia futurista was characterized by an unusually high number of women. ${ }^{54}$ The Florentine periodical contained many articles, poems, reviews or Parole in libertà by Fulvia Giuliani, Irma Valeria, Eva Kuhn Amendola (alias Magamal), Emma Marpillero, Enif Robert, Mina della Pergola, Fanny Dini, Enrica Piubellini and Marj Carbonaro. Furthermore, the writer Maria Ginanni (1891-1953) was also the editor of Edizioni de l'Italia futurista which published Futurist books. The debate on gender among Futurists could also be understood as a reaction to Marinetti's Come si seducono le donne (How to Seduce Women, 1917), a controversially discussed book. Mari Annetta (alias Comtesse du Aubrun), for example, wrote a parody titled Come si seducono gli uomini (How to Seduce Men, 1918). ${ }^{55}$ The lively discussion created a new column in the L'Italia futurista, called Donne-amore-bellezza (Women-Love-Beauty). It is remarkable that the women who published in this column did not express a uniform opinion. Instead, they described very diverse ideas of the new "image of women". Edyth's reflections also

52 So far, this four-color drawing has not been dealt with in Futurist research. It is only due to an entry on the artist in the archive of Artglobal that the author is familiar with it: http://www.artglobal.cn/artist/readit.php?newsid=1803 (accessed on December 12, 2012). Unfortunately, this page can no longer be accessed. It cannot be said for sure whether this drawing is a forgery.

53 See also $R e, 1994$, p. 319. Edyth's texts were published in 1917: "Le donne del posdomani" (The Women of the Day after Tomorrow), in: L'Italia futurista, No. 18 (June 17, 1917), p. 1; "Risposta a Jean-Jacques" (Reply to Jean-Jacques), ibid. No. 20 (July 1, 1917), p. 2, and "Le donne cambiano finalmente" (Women Finally Change), ibid. No. 27 (Aug. 26, 1917), p. 2. Valentina Mosco also provides a profound analysis of Rosà's texts in her subchapter "Rosa Rosà, futurista protofemminista?”, in: Mosco, 2009, pp. 116-121; Re, 1989,pp. 263-269, as well as Re, 2014, pp. 184-187. Renate Berger also addressed the situation of women who tried to establish themselves as artists, see Berger, 1982.

54 A very rare phenomenon at that time which also characterized the artistic group AENIGMA founded in Munich (1918-ca.1928). Their works, in turn, were strongly influenced by anthroposophical thinking. Reinhold J. Fäth argued this in his lecture "Artists within and around the group AENIGMA (1918-ca. 1928)", delivered on Sept. 27, 2013 at the conference Enchanted Modernities: Theosophy, Modernism and the Arts, c. 1875-1960, in Cambridge.

55 Marinetti, 1917, and Annetta, 1918. 
opposed the female ideal of the housewife and mother glorified by the regime of Benito Mussolini. Nevertheless, she participated in the exhibitions Associazione Nazionale Fascista Donne Artiste e Laureate during the 1930s. ${ }^{56}$

The artist herself reflected on the impressive complexity of her situation by stating that she was "not a Feminist but 'an -ist' for which the first part of the word has yet to be found". ${ }^{57}$ Elaborating on this thought, she may well have refused to be called a "Spiritist" even though spiritism played a major role in her life. Also, the denomination "Futurist" seems out of the question for her. Yet, her participation in the Futurist movement turned out to be quite successful, even though she was an Austrian living in Italy at the beginning of World War I and a wife and mother of four children. Certainly, her connection to Italian Futurism helped her overcome the boundaries of her bourgeois life and to become a versatile, self-transforming woman "with many souls." The way to achieve all this, as I suggest, was paved by her interest in spiritism. Several studies from different perspectives have examined the artist and her work; however, a monograph of her complete works still remains a desideratum. ${ }^{58}$ This is complicated by the fact that only a small number of her works are extant, some of which are in part only documented by correspondence, photographs or auctions. ${ }^{59}$ For example, the colored drawing, Mona Vanna (Fig. 5), presumably done in the 1920s, has not yet been studied by Futurism scholars. It may have been the artist's attempt to include the meaning of color tones, but unfortunately only a black and white picture has so far been found. ${ }^{60}$ The predominantly abstract drawing is reminiscent of some of Gustav

56 These documents are mentioned by Pancotto, 2004, p. 28. Edyth's anti-Fascist attitude culminated in 1943 when she was prosecuted and arrested for having helped a Jewish family. This is documented by Proietti, 2017, p. 40. On the activities of the Associazione Nazionale Fascista Donne Artiste e Laureate and the strained relationship between the female artists and Mussolini's regime, see Spinazzè, 2001.

57 "Lei vede, non sono femminista. - Sono un'<ista>, percui la prima parte della parola ancora non è trovato", see Rosà, 1917, L'Italia futurista 2(20), p. 2.

58 See for example Salaris, 1982; Bello Minciacchi, 2007; Bentivoglio/Zoccoli, 2008; Carpi, 2009; Verdone, 1971; Verdone, 1995; Salaris, 1981; Hanstein, "Edyth von Haynau”, 2015; Hanstein 2019; Proietti, 2017. Lanza's publication reads more like a narrative than a scientific study, see Lanza, 2014.

59 A direct view of an abstract painting by Edyth is only provided by a photograph from 1919 which shows the artist working on the picture titled "Bandiere", reproduced in Salaris, 1981, p. 26. Maria Luisa Fiumi documents the expressiveness of several paintings which were exhibited in the Lyceum, see Fiumi, 1922, p. 23.

60 The drawing was listed in an auction of the Munich auction house Neumeister, see Neumeister, 1994. For more information, see also Hanstein, "Edyth von Hay- 
Klimt's (1862-1918) depictions of women. Strongly simplified, the painting shows the silhouette of a woman with her arms bent, leaning slightly to the right. To her left, the same representation appears from another angle. The oval forms surrounding the women are painted in different sizes and densities, which evoke an association with eyes. This could be interpreted as another example of Edyth's visualization of a modern woman, as the title can be understood as an allusion to the play Monna Vanna (1902) by Maurice Maeterlinck (1862-1949), which introduced a new type of woman. ${ }^{61}$ The play's overturning of traditional role models and depiction of a self-determined woman would be perfectly in line with Edyth's interests. In another book, Maeterlinck analyzed the figure of the medium and his extrasensory abilities - in a similar vein to the novel Sam Dunn è morto —and thus, it is likely that Edyth was familiar with him. ${ }^{62}$

Later on, Edyth was to produce colored drawings for two fairy tale books by Ernst Roenau, albeit without any Futurist elements. ${ }^{63}$ The only oil painting known to this day, Anticolana alla fonte, probably created before 1935 , shows a woman with a headscarf carrying a clay vessel. ${ }^{64}$ The motif of working women can also be found in some of Edyth's photographs held by the Alinari Archive-this attests to the artist's lasting interest in the depiction of women. ${ }^{65}$ Working into old age, Edyth produced several novels and drawings before she died in Rome in 1978.

Examining her artistic and literary works as a whole is the prerequisite for an international treatment of her body of work. Therefore, traces of her lost works will be sought in archival materials and auctions, and will be analyzed against the backdrop of her post-Futurist work and the rarely

nau”, 2015, pp. 353-354. At the same auction, three other drawings by Edyth were for sale ("The Widow", "Salome" and "Cherchez la femme"). Unfortunately, the new owner has not been identified yet which is why the authenticity of the works remains in question.

61 For more on this play, see the observations in Goldman, 1914, pp. 129-137.

62 Růžena's interest in Maurice Maeterlinck's book L'Hote inconnu from 1917 (original English edition: 1914) is documented, see Giorgini, 2012, p. 113.

63 Roenau, 1922; Roenau, 1923.

64 Reproduced in Pancotto, 2004, p. 54.

65 Ferruccio Malandrini's collection also contains many photographs of activities taking place during the annual Palio in Siena. The collection is mentioned by Lanza, 2014, p. 121. Unfortunately, only photographs and no other drawings or works by the artist are part of it. Both archives can be consulted online: https://w ww.alinari.it/it/ricerca?q=edith+arnaldi as well as https://opereweb.fondazionemp s.it/Malandrini.aspx? $\mathrm{p}=8$. An overview of her known works and her exhibitions is given by Hanstein, "Edyth von Haynau", 2015, pp. 335-338. 
studied photographs, in order to redefine Edyth's role within the context of Italian modernism and the development of a newly emerging image of women.

\section{REFERENCES}

Annetta, Mari. (1918). Come si seducono gli uomini. Cappelli.

Asendorf, Christoph. (1989). Ströme und Strahlen: Das langsame Verschwinden der Materie um 1900. Anabas.

Bello Minciacchi, Cecilia. (Ed.). (2007). Spirale di dolcezza + serpe di fascino: Scrittrici futuriste, Antologia. Bibliopolis.

Bentivoglio, Mirella, and Franca Zoccoli. (Eds.). (2008). Le futuriste italiane nelle arti visive. De Luca.

Benzi, Fabio. (2007). Giacomo Balla: Genio futurista. Electa.

Berger, Renate. (1982). Malerinnen auf dem Weg ins 20. Jabrhundert. Kunstgeschichte als Sozialgeschichte. DuMont.

Berghaus, Günter. (2015). Editorial. In Günter Berghaus (Ed.), International Yearbook of Futurism Studies (Vol. 5). Special Issue: Women Artists and Futurism, XIXXII. De Gruyter.

Calvesi, Maurizio. (1967). Penetrazione e magia nella pittura di Balla. In Maurizio Calvesi (Ed.), Dinamismo e simultaneità nella poetica futurista, 121-160. Fabbri.

Carli, Mario. (1918). Notti filtrate. 10 liriche di Mario Carli, 10 disegni di Rosa Rosà. Edizioni de "L'Italia futurista".

Carpi, Giancarlo. (Ed.). (2009). Futuriste: Letteratura, arte, vita. Castelvecchi.

Cigliana, Simona. (2002). Futurismo esoterico: Contributi per una storia dell'irrazionalismo italiano tra Otto e Novecento. Liguori.

Contarini, Silvia. (2015). Valentine de Saint-Point. A futurist woman? In Günter Berghaus (Ed.), International Yearbook of Futurism Studies (Vol. 5). Special Issue: Women Artists and Futurism, 87-110. De Gruyter.

Corra, Bruno. (1917). Sam Dunn è morto: Romanzo sintetico futurista. Studio Editoriale Lombardo.

Dalrymple Henderson, Linda. (1995). Die moderne Kunst und das Unsichtbare: Die verborgenen Wellen und Dimensionen des Okkultismus und der Wissenschaften. In Veit Loers (ed.), Okkultismus und Avantgarde: Von Munch bis Mondrian 1900-1915, 13-31. Edition Tertium.

Fiumi, Maria Luisa. (1922). Edyth Arnaldi (Rosà). La donna: Rivista quindicinale illustrata 347, 23-24.

Giorgini, Marina. (2012). Růžena Zátková e i futuristi a Roma nel secondo decennio del Novecento. In Valentina Moncada di Paternò and Maria Chiara Salmeri (Eds.), Atelier a via Margutta: Cinque secoli di cultura internazionale a Roma, 110116. Allemandi. 
Goldman, Emma. (1914). Monna Vanna: An Analysis of the Play by Maurice Maeterlinck. In Emma Goldman (Ed.), The Social Significance of the Modern Drama, 129-137. Badger.

Grasso, Monica. (2001). Donne e scultura (1920-1943): Temi, tecniche, tipologie. In Laura Iamurri \& Sabrina Spinazzè (Eds.), L'arte delle donne nell'Italia del Novecento, 137-151. Meltemi.

Hanstein, Lisa. (2015). Edyth von Haynau: A Viennese Aristocrat in the Futurist Circles of the 1910s. In Günter Berghaus (Ed.), International Yearbook of Futurism Studies (Vol. 5). Special Issue: Women Artists and Futurism, 333-365. De Gruyter.

Hanstein, Lisa. (2015). Der Geist der Moderne. Die verborgene Seite des italienischen Futurismus. [Dissertation, Goethe University Frankfurt].

Hanstein, Lisa. (2019). Durch Rosas Brille: Die graphische Interpretation von Sam Dunn ist tot. In Bruno Corra (Ed.), Sam Dunn ist tot. Futuristischer Roman. 115141. Arco Verlag.

Harriman, Helga H. (1989). Olga Wisinger-Florian and Tina Blau: Painters in 'Fin de Siècle' Vienna. Woman's Art Journal 10(2), 23-28.

Heindl, Waltraud, and Marina Tichy. (1990). "Durch Erkenntnis zu Freibeit und Glück ...": Frauen an der Universität Wien (ab 1897). WUV-Universitätsverlag.

Kury, Astrid. (1998). Spiritismus: Die neue Religion. Wissenschafts- und Gesellschaftskritik um 1900 und ihre Auswirkungen auf die zeitgenössische Malerei. In Sonja Rinofner-Kreidl (Ed.), Zwischen Orientierung und Krise: Zum Umgang mit Wissen in der Moderne, 381-433. Böhlau.

Kury, Astrid. (2000). Heiligenscheine eines elektrischen Jahrhundertendes sehen anders aus . . . : Okkultismus und die Kunst der Wiener Moderne. Passagen.

Lanza, Cesare. (2014). Rosa Rosà: Edyth, tra futurismo e femminismo, storia di una donna versatile nelle arti, coraggiosa nelle battaglie civili. L'attimo fuggente editore.

Maeterlinck, Maurice. (1917). L'hôte inconnu. Charpentier, 1917 (Original English version from 1914. The Unknown Guest. Methuen).

Magamal [Eva Kühn Amendola]. (1917). Sam Dunn è morto. L'Italia futurista $2(28), 3$.

Magnus, Hugo. (1877). Die geschichtliche Entwicklung des Farbensinnes. Verlag von Veit \& Comp.

Marinetti Cappa, Benedetta. (1924). Le forze umane: Romanzo astratto con sintesi grafiche. Campitelli.

Marinetti, Filippo Tommaso. (1917). Come si seducono le donne. Centomila Copie.

Marinetti, Filippo Tommaso. (1983). L'uomo moltiplicato e il regno della macchina. In Luciano de Maria (Ed.), Teoria e invenzione futurista, 255-258. Mondadori.

Marinetti, Filippo Tommaso, and Alberto Viviani. (1992). Firenze biondazzurra sposerebbe futurista morigerato. Sellerio.

Meazzi, Barbara. (2019). Women Futurists in Italy: A Research Report. In Günter Berghaus (Ed.), Handbook of International Futurism. 450-464. De Gruyter. 
Meighan, Judith Ellen. (1998). The Stati d'animo aesthetic: Gaetano Previati, Umberto Boccioni and the Development of Early Futurist Painting in Italy. [Dissertation, Columbia University].

Mosco, Valentina. (2009). Donna e futurismo, fra virilismo e riscatto. Centro Editoriale Toscano.

Moncada di Paternò, Valentina, and Maria Chiara Salmeri (Eds.). (2012). Atelier a via Margutta: Cinque secoli di cultura internazionale a Roma. Allemandi.

Neumeister, Rudolf. (1994). Auktionskatalog Auktion Jugendstil, angewandte Kunst und Kunst des 20. Jahrhunderts. Auction Catalog, 19 November 1994. Gotteswinter.

Notte, Riccardo. (2002). Esoterismo. In Ezio Godoli (Ed.), Il dizionario del futurismo. 412-416. Vallecchi.

Palczewska, Grazyna, Frans Vinberg, Patrycjusz Stremplewski, Martin P. Bircher, David Salom, Katarzyna Komar, Jianye Zhang, Michele Cascella, Maciej Wojtkowski, Vladimir J. Kefalov, and Krzysztof Palczewski. (2014). Human infrared vision is triggered by two-photon chromophore isomerization. Proceedings of the National Academy of Sciences, 16 December, 111(50), 5445-5454. Retrieved March 8, 2020, from http://www.pnas.org/content/111/50/E5445.full.

Pancotto, Pier Paolo, (Ed.). (2004) Pittrici nella valle dell'Aniene. Anticoli Corrado: Civico Museo d'Arte Moderna, 18 gennaio - 22 febbraio 2004. [Exhibition cata$\log$ ]. Edizioni Iter.

Pirandello, Luigi. (1921). Uno, nessuno e centomila. Cronache d'attualità: Arte, scienza, letteratura, teatro, mode, sport, mondanità 3(5), 4.

Pizzo, Gian Filippo, and Luca Somigli. (2006). Science Fiction. In Gaetana Marrone, Paolo Puppa and Luca Somigli (Eds.), Encyclopedia of Italian Literary Studies: A-J (Vol. 2), 1717-1721. Routledge.

Plakolm-Forsthuber, Sabine. (1994). Künstlerinnen in Österreich 1897-1938: Malerei, Plastik, Architektur. Picus.

Poggianella, Sergio. (1995). Okkulte Elemente und das Licht im Werk Ballas. In Veit Loers (Ed.), Okkultismus und Avantgarde: Von Munch bis Mondrian 19001915. 459-469. Edition Tertium.

Pomajzlová, Alena. (2011). Růžena: př́běh maliřky Růženy Zátkové = Růžena: story of the painter Rüžna Zátková. Arbor Vitae Societas a Porte.

Proietti, Simonetta. (2017). Edith von Haynau (Rosa Rosà). Una donna tra futurismo e politica, [Dissertation, Roma Tre University].

Pytlik, Priska. (2005). Okkultismus und Moderne: Ein kulturhistorisches Phänomen und seine Bedeutung für die Literatur um 1900. Schöningh.

Re, Lucia. (1989). Futurism and Feminism. Annali d'Italianistica (Vol. 7), Women's Voices in Italian Literature, 253-272.

Re, Lucia. (2011). Rosa Rosà's Futurist-Feminist Short Novel A Woman With Three Souls: A Critical Introduction. California Italian Studies 2(1), 1-15.

Re, Lucia. (2014). Rosa Rosà and the Question of Gender in Wartime Futurism. In Vivien Greene (ed.), Italian Futurism 1909-1944: Reconstructing the Universe. 184187. Solomon R. Guggenheim Museum. 
Re, Lucia and Charlotte Douglas. (2019). Women Futurists. In Günter Berghaus (Ed.), Handbook of International Futurism, 47-66. De Gruyter.

Re, Lucia. (1994). Scrittura della metamorfosi e metamorfosi della scrittura: Rosa Rosà e il futurismo. In Emanuelle Genevois, and Danièle Valin (eds.), Les Femmes-écrivains en Italie (1870-1920): Ordres et libertés, 311-327. Université de la Sorbonne Nouvelle.

Roenau, Ernst. (1922). Das Persische Papageienbuch. Book ornamentation by Rosà. Wolf.

Roenau, Ernst. (1923). Tausendundeine Nacht. Pictures and drawings by Rosà. Graphische Anstalt.

Rosà, Rosa (Edyth Arnaldi, Edyth von Haynau). (1917). Moltitudine. L'Italia futurista, 2(9), 3.

Rosà, Rosa (Edyth Arnaldi, Edyth von Haynau). (1917). Romanticismo sonnambulo. L'Italia futurista 2(17), 3.

Rosà, Rosa (Edyth Arnaldi, Edyth von Haynau). (1917). Le donne cambiano finalmente... L'Italia futurista 2(27), 2.

Rosà, Rosa (Edyth Arnaldi, Edyth von Haynau). (1917). Le donne del posdomani. L'Italia futurista 2(18), 1.

Rosà, Rosa (Edyth Arnaldi, Edyth von Haynau). (1917). Risposta a Jean-Jacques... L'Italia futurista 2(20), 2.

Rosà, Rosa (Edyth Arnaldi, Edyth von Haynau). (2011). Rosa Rosà's 'A Woman with Three Souls' in English Translation. California Italian Studies 2(1) (Lucia Re and Dominic Siracusa, Trans.), 15-39.

Rosà, Rosa (Edyth Arnaldi, Edyth von Haynau). (1981). Una donna con tre anime. Claudia Salaris (Ed.). Edizioni delle Donne.

Rosà, Rosa (Edyth Arnaldi, Edyth von Haynau). (1918). Una donna con tre anime. Romanzo futurista. Studio Editoriale Lombardo.

Russolo, Luigi. (1938). Al di là della materia. Alla ricerca del vero, alla ricerca del bello, alla ricerca del bene (Piccola biblioteca di scienze moderne, 427). Bocca.

Ruta, Anna Maria. (2019) Decorative Art, Furniture and Interior Design. In Günter Berghaus (Ed.), Handbook of International Futurism, 175-192. De Gruyter.

Salaris, Claudia. (1981). Introduzione. In Claudia Salaris (Ed.), Una donna con tre anime, 7-26. Edizioni delle Donne.

Salaris, Claudia. (1981). Nota bibliografica. In Claudia Salaris (Ed.), Una donna con tre anime, 27-28. Edizioni delle Donne.

Salaris, Claudia. (1982). Le futuriste: Donne e letteratura d'avanguardia in Italia (1909/1944). Edizione delle Donne.

Salaris, Claudia. (2001). Incontri con le futuriste. In Laura Iamurri and Sabrina Spinazzè (Eds.), L'arte delle donne nell'Italia del Novecento, 50-66. Meltemi.

Schiaffini, Ilaria. (2002). Umberto Boccioni: Stati d'animo. Teoria e pittura. Silvana.

Schöntag, Roger. (2005). Hugo Magnus im Zentrum der Farbendiskussion des 19. Jahrhunderts. Zeitschrift für Ethnologie, 130(2), 293-316. 
Sica, Paola. (2004). Una donna con tre anime di Rosa Rosà: Un romanzo protofemminista. Italian Quarterly 41(159-160), 75-82.

Sica, Paola. (2016). Futurist Women. Florence, Feminism, and the New Sciences. Palgrave Macmillan.

Spinazzè, Sabrina. (2001). Donne e attività artistica durante il Ventennio. In Laura Iamurri and Sabrina Spinazzè (Eds.), L'arte delle donne nell'Italia del Novecento, 121-136. Meltemi.

Verdone, Mario. (1995). Abstraktion, Futurismus und Okkultismus: Ginna, Corra und Rosà. In Veit Loers (Ed.), Okkultismus und Avantgarde: Von Munch bis Mondrian 1900-1915. Edition Tertium.

Verdone, Mario. (1971). Disegni futuristi e astratti di Rosa Rosà. Didattica del disegno: Rivista di storia e tecnica del disegno 2(3), 52-56.

Zoccoli, Franca. (2000). Futurist Women Painters in Italy. In Günter Berghaus (Ed.), International Futurism in Arts and Literature, 373-397. De Gruyter.

Zoccoli, Franca. (2019). Italian Fashion Design. In Günter Berghaus (Ed.), Handbook of International Futurism, 144-153. De Gruyter.

\section{ARCHIVAL SOURCES}

Fondazione Primo Conti, Fiesole, Italy, FC/ES.C 143-145 CAM A "Letter of Rosa Rosà (Edyth Arnaldi, Edyth von Haynau) to Emilio Settimelli”, 11 April 1921, and "Letter of Rosa Rosà (Edyth Arnaldi, Edyth von Haynau) to Emilio Settimelli”, 2 September 1923.

\section{MANIFESTOS}

Filippo Tommaso Marinetti, Manifesto del futurismo (Le Figaro, 20 February 1909)

Bruno Corra, Arnaldo Ginanni, Remo Chiti, Emilio Settimelli, Mario Carli and Oscar Mara, La scienza futurista (antitedesca - avventurosa - capricciosa - sicurezzofoba-ebbra d'ignoto) (L'Italia futurista 1(2), 15 June 1916)

\section{LIST OF ILLUSTRATIONS}

Figure 1. Edyth von Haynau: Parole in libertà "Ricevimento - thé - signore - nessun uomo", in L'Italia futurista 2:35 (9 December 1917), p. 3. Source: Kunsthistorisches Institut in Florenz - Max-Planck-Institut.

Figure 2. Edyth von Haynau: "Danzatrice", in Cronache d'attualità. Arte, scienza, letteratura, teatro, mode, sport, mondanità, Roma, Maggio 1921, p. 4. Source: Kunsthistorisches Institut in Florenz - Max-Planck-Institut. 
Figure 3. Edyth von Haynau (?): Possibly a preliminary drawing of the fifth illustration in Carli, Mario: Notti filtrate. (C) 2013 Sino Artglobal, Co., Ltd. Copyright. YUE ICP BEI 13021223. http://www.artglobal.cn/work/readit.php?newsid=1804

Fig. 4. Edyth von Haynau: Without title, in Mario Carli: Notti filtrate. 10 liriche di Mario Carli, 10 disegni di Rosa Rosà, Firenze: Edizioni de "L'Italia futurista", 1918, (no pagination). Source: Kunsthistorisches Institut in Florenz - MaxPlanck-Institut.

Fig. 5. Edyth von Haynau: "Mona Vanna”, in: Rudolf Neumeister: Auktion Jugendstil - angewandte Kunst und Kunst des 20. Jahrhunderts. Auction Catalog, 19 November 1994, p. 56. CNEUMEISTER, München.

The permission for publication of the works of Edyth von Haynau was kindly given by Cristina Fornari, Luca Fornari and Ranieri Fornari.

Figure 1. Edyth von Haynau: Parole in libertà "Ricevimento - thé - signorenessun uomo" (Reception-Tea-Ladies-No Men)

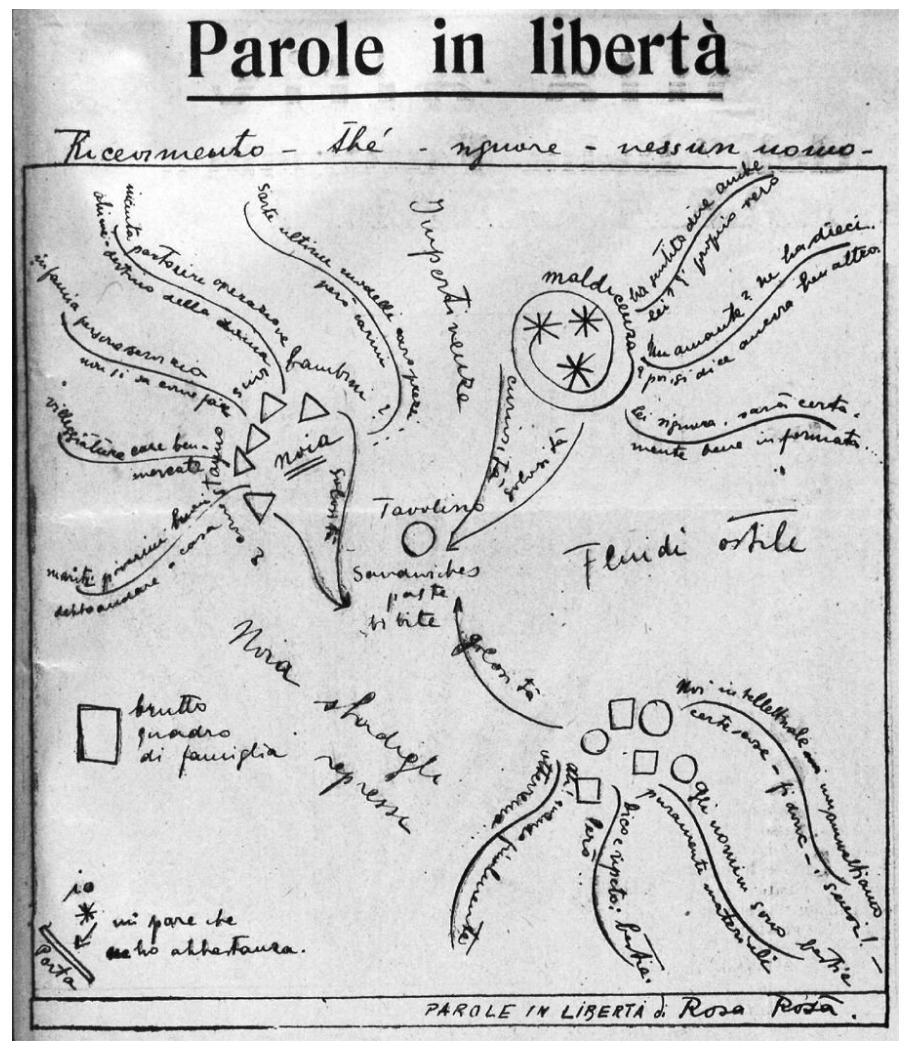


Figure 2. Edyth von Haynau: "Danzatrice" (The Female Dancer)

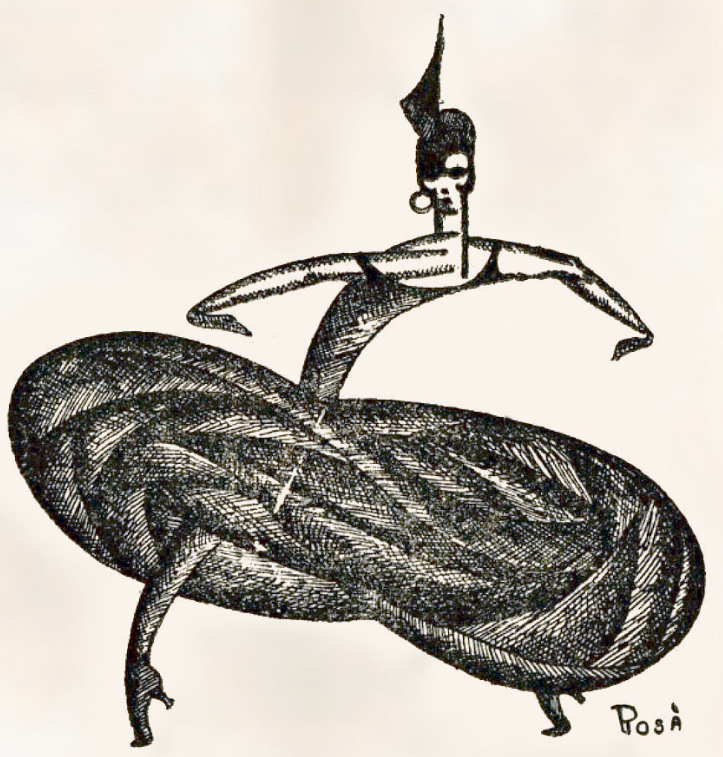

Figure 3. Edyth von Haynau (?): Possibly a preliminary drawing of the fifth illustration in Carli, Mario: Notti filtrate.

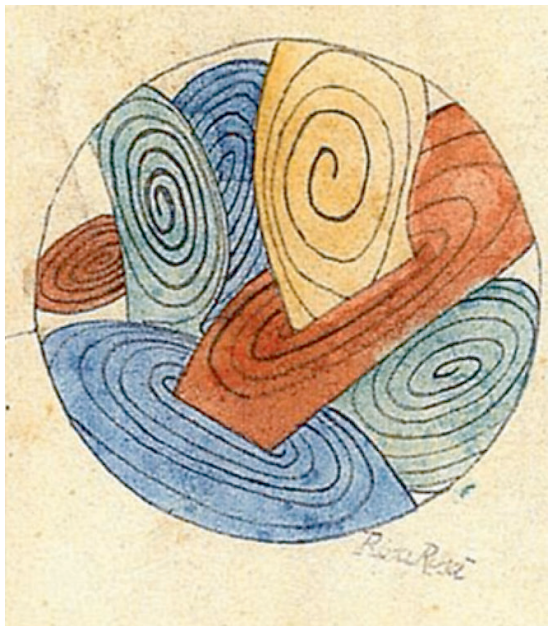


Figure 4. Edyth von Haynau: no title, in Carli, Mario: Notti filtrate

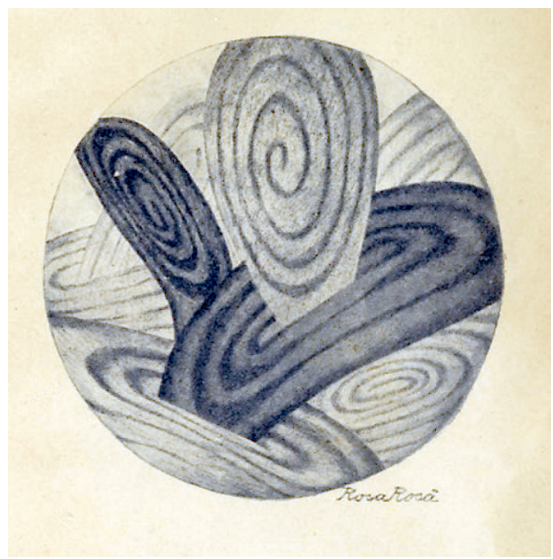

Figure 5. Edyth von Haynau: "Mona Vanna"

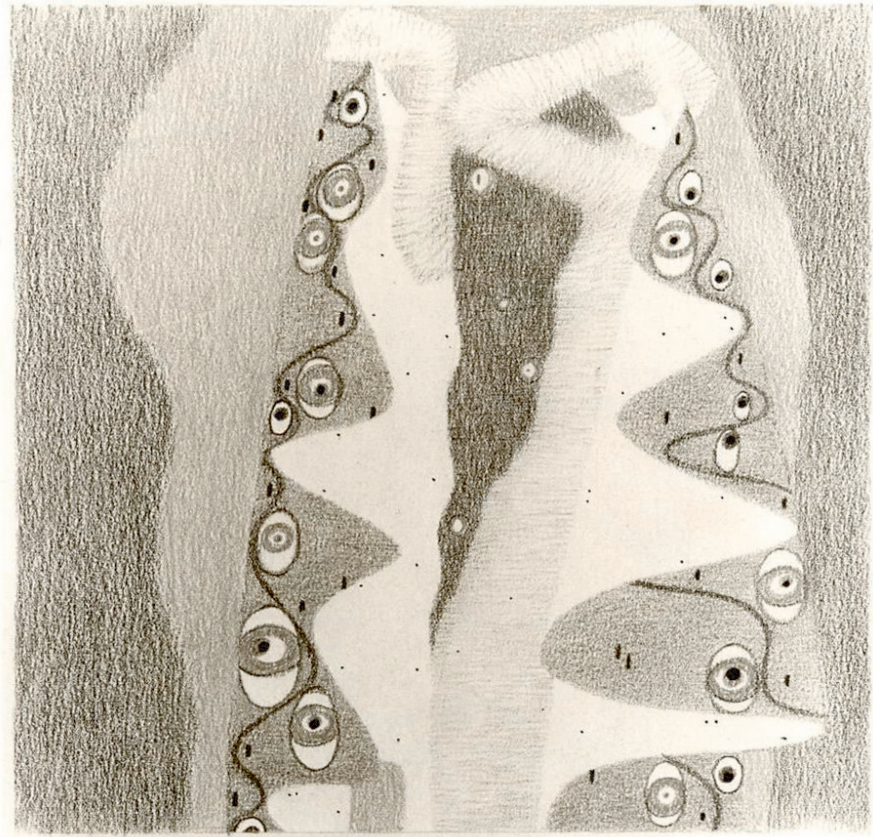

MONA VANMA 


\section{Dr. Lisa Hanstein}

Lisa Hanstein received her $\mathrm{PhD}$ in art history from Goethe University Frankfurt in 2015 and currently holds the position of Academic Assistant in the library at the Kunsthistorisches Institut in Florenz - Max-Planck-Institut, in Florence. In 2018 she completed her Masters in Library and Information Science and was presented with the Ulrich-Hahn-Award in 2004. She specializes in Italian Futurism, focusing on the impact of psychology, spiritism and science on Italian Futurist art. Surprisingly, many female Futurists showed an interest in paranormal phenomena. This led to her current research project on Edyth von Haynau, which is also particular interesting in terms of the role of women in Italy in the early twentieth century. The institute's library holds a special collection on Futurism which, in conjunction with the two directors and their staff, provides an excellent scientific environment for studying Futurism. She co-organized a conference at the Institute on the role of Italian Futurism within the broader context of international avant-garde movements and co-curated the related publication "Altri futurismi", the Futurist online exhibition "ZANG TUMB TUUM...", as well as the digital archive on Futurism in Florence "PRO FIRENZE FUTURISTA". She has published several articles on Futurism and on the Institute's Futurism Archive.

\section{Selected Publications:}

Hanstein, Lisa. (2019). Durch Rosas Brille: Die graphische Interpretation von Sam Dunn ist tot. In Bruno Corra (Ed.), Sam Dunn ist tot. Futuristischer Roman. (Magnus Chrapkowski, Trans.) (pp. 115-141). Wuppertal: Arco Verlag.

Hanstein, Lisa. (2015). Der Geist der Moderne. Die verborgene Seite des italienischen Futurismus. [Dissertation, Goethe University Frankfurt].

Hanstein, Lisa. (2015). Edyth von Haynau: A Viennese Aristocrat in the Futurist Circles of the 1910s. In Günter Berghaus (Ed.), International Yearbook of Futurism Studies (Vol. 5). Special Issue: Women Artists and Futurism (pp. 333-365). Berlin: De Gruyter. 


\section{Kunsthistorisches Institut in Florenz - Max Planck Institute}

The Kunsthistorisches Institut in Florenz (KHI) is a research institute dedicated to the history of art and architecture. Its main focus is on the art and visual culture of Italy, Europe, and the Mediterranean in a global perspective. Founded in 1897 on a private initiative of a group of scholars, the $\mathrm{KHI}$ is one of the oldest institutions for art-historical research. It has been part of the Max Planck Society since 2002. The KHI is particularly committed to supporting, advancing and connecting international young academics.

It has an extensive Library and Photothek which are open for international research. The Library's holdings today cover the history of European art and culture, focusing on Italy, from Late Antiquity to the present day, concentrating on topics relating to the intercultural, international, intercontinental and interdisciplinary contextualization of Italian art. The original works of Futurism are part of the Library's specialist collections.

Current individual and collaborative projects at the KHI are concerned with a variety of subjects, such as transcultural dynamics, ethics and architecture, history of science and of museums, photography, the relationship between aesthetics and ecology, languages of art and art history, image/ language, and interactions between discourses on images and objects. 